\title{
Extent of Adoption of Sweet Corn Cultivation in South Eastern Ghat Zone of Odisha
}

\author{
Samir Ranjan Dash ${ }^{1}$, Anuj Kumar Rai ${ }^{1}$, Himangshu Das ${ }^{2^{*}}$, Nigamananda Behera ${ }^{1}$ and \\ Subhasis Dash ${ }^{3}$
}

${ }^{1}$ Krishi Vigyan Kendra Malkangiri (OUAT), Malkangiri, Odisha, India

${ }^{2}$ Regional Research \& Technology Transfer Sub-Station, Kalimela (OUAT), Malkangiri, Odisha, India

${ }^{3}$ Krishi Vigyan Kendra Jajpur (OUAT), Jajpur, Odisha, India

"Corresponding author: hdubkv@gmail.com (ORCID ID: 0000-0003-1568-9544)

Paper No. 856

Received: 22-03-2020

Revised: 25-07-2020

Accepted: 20-08-2020

\begin{abstract}
Sweet corn is becoming very popular in different parts of the country. The present study was conducted during 2019-20 in two blocks of Malkangiri district comprising 120 numbers of farmers from four adopted villages of Krishi Vigyan Kendra, Malkangiri in South Eastern Ghat Zone of Odisha. In previous years (2017-18 and 2018-19) KVK, Malkangiri has conducted FLD programmes on sweet corn cultivation by providing the critical inputs with support of production technologies. Conducting front line demonstrations on farmer's field help to identify potential of the sweet corn in specific area as well as it helps in improving the economic and social status of the farmers. The ex-post facto research design was used for the study. Majority of the respondents $(83.3 \%)$ were found to possess medium to high level of adoption behavior regarding different recommended package and practices about sweet corn cultivation. It means that the respondents were more energetic, progressive and adopting the sweet corn as cash crop keeping the market demand in mind and practicing the technologies for better production and higher net return. The study revealed that socio- economic variable like education, extension contact, communication material used and holding size were the pertinent variables exhibiting influence towards adoption behaviour of the respondents. Different extension agencies like KVK, ATMA, NGO's of the district need to provide more technical support to the farmers for increase in area and production of sweet corn.

Highlights

( Majority of the respondents (83.3\%) were found to possess medium to high level of adoption behavior regarding different recommended package and practices about sweet corn cultivation.

( Socio-economic variables like education, extension contact, communication material used and holding size were the pertinent variables exhibiting influence towards adoption behaviour of the respondents.
\end{abstract}

Keywords: Adoption, cultivation, front line demonstration, sweet corn

Maize (Zea mays L.) is a vital food crop and gives a big volume of raw materials for farm animals and many agro-related industries in the world (Bello et al. 2010; Randjelovic et al. 2011). Sweet corn (Zea mays L. var. saccharata) also called sugar corn and pole corn is a variety of maize with high sugar content. Unlike field corn varieties, which are harvested when the kernels are dry and mature, sweet corn is picked when immature (milk stage) and prepared and eaten as vegetable, rather than as a grain. Sweet corn is favorable for fresh consumption because of its delicious taste, soft and sugary texture as compared to other corn varieties; the kernels have high sugar content in the milk on early dough stage. The taste of sweet corn kernels

How to cite this article: Dash, S.R., Rai, A.K., Das, H., Behera, N. and Dash, S. (2020). Extent of Adoption of Sweet Corn Cultivation in South Eastern Ghat Zone of Odisha. IJAEB, 13(3): 349-353.

Source of Support: None; Conflict of Interest: None (c) 
is $25-30 \%$ sweeter than normal corn. At optimum market maturity, sweet corn contains 10 - 11\% starch, $3 \%$ water-soluble polysaccharides and $70 \%$ water; it also contains moderate levels of protein, vitamin A and potassium (Najeeb 2011; Walker 2018). Sweet corn is one type of maize which is morphologically no different from corn the difference is only in the higher sugar content when the stadia immature grains/milk stage with a sugar content of about $13 \%$ to $15 \%$ (Bhatt, 2012). In food commodities, there is a huge demand for sweet corn because it contains high vitamins $\mathrm{A}$ and vitamin $\mathrm{C}$ as well as low fat as compared to normal corn in addition to high contains of sugar (Adinurani et al. 2019). Therefore, efforts are made to increase the yield of sweet corn through improving the cultivation practices. Among the factors which influence the yield of maize, improved seed varieties, plant population and fertilizer are the most important.

Front line demonstration (FLD) is one of the important tools for transfer of technology. Conducting cluster front line demonstrations on farmer's field help to identify the constraints and potential of the any crop in specific area as well as it helps in improving the economic and social status of the farmers. The field demonstrations conducted under close supervision of scientists of the National Agricultural Research System is called front line demonstration because the technologies are demonstrated for the first time by the scientist themselves before being fed into the main extension system of the state department of agriculture (Venkatasubramanian et al. 2010). The main objective of FLD is to demonstrate newly released crop production technologies and its management practices in the farmers' field under different farming situations and at different agro-climatic regions. The newly and innovative technology having higher production potential under the specific cropping system can be popularized through front line demonstrations programme. The aim of the front-line demonstration is to convey the technical message to farmers that if they use recommended package and practices then the yield of crop can be easily increase than their present level. Keeping the above point in view, the FLDs on Sweet corn using improved production technologies were conducted by Krishi Vigyan Kendra, Malkangiri and later an investigation was under taken to assess the extent of adoption level of the farmers about recommended technologies of sweet corn as well as contribution of socio-economic attributes of the farmers influencing adoption behavior about different recommended package and practices.

\section{MATERIALS AND METHODS}

The district Malkangiri is counted as most backward tribal dominated district of the state of Odisha with $61 \%$ people remaining under poverty line and literacy rate is only $30.53 \%$ (Priyambada 2017). This study has been conducted in the Malkangiri district of South Eastern Ghat Zone of Odisha covering two blocks namely Malkangiri and Kalimela in winter season of 2019-20. The blocks were selected purposively because these blocks were leading in terms of area and production of sweet corn cultivation in the district. A sample size of 120 sweet corn growers randomly selected from four villages namely MV2, MV9 of Malkangiri block and MPV-67, MV-90 of Kalimela block. Previously front line demonstration on cultivation were conducted in same places during winter season of 2017-18 and 2018-19 and seeds of high yielding sweet corn varieties like Sugar 75 and Madhuri with other critical inputs were provided to the farmers.

The ex-post facto research design was used for the study and Multi-stage stratified sampling procedure was employed for selection of blocks, villages and sweet corn growers. From each village 30 numbers of farmers were selected through population proportion to sample size technique covering two blocks, as the respondents. The socioeconomic variables as age, education, family type, family size, social participation, cosmopoliteness, extension contact, communication materials used, house type, holding size, occupation and annual income were selected as the independent variables for the study. The dependant variable in the study was knowledge and adoption level of the farmers. To collect data semi- structured interview schedule was developed and it was pre-tested and modified accordingly for assembling the relevant data. Percentage and frequency were used to measure Knowledge and adoption of contact farmers. The other selected independent variables like age, education, land holding, annual income, extension participation, innovativeness, risk orientation, scientific orientation and mass media participation were measured 
by using already developed scales by the earlier researchers. Finally the data were tabulated and analyzed by using frequency, percentage, mean, SD and Pearson's Coefficient of correlation " $r$ " to draw the inferences.

\section{RESULTS AND DISCUSSION}

The selected sweet corn growers were asked to indicate the adoption of different recommended technologies through a structured suitable schedule and the information collected by interviewing the selected growers and tabulated them to identify the level of adoption of different practices. The suitable statistical tools like percentage, mean, Standard deviation were used for analysis and interpretation of the data.

\section{Adoption Behavior}

The results revealed that $53.3 \%$ respondents had medium adoption behavior, $30.0 \%$ had high rate of adoption and $16.7 \%$ of respondents having low adoption of different recommended practices of sweet corn cultivation (Table 1). As the farmers were conducting participatory FLDs under the guidance of KVK scientists and due to regular training and capacity programmes conducted in the operational areas and majority $(83.3 \%)$ of farmers had medium and high level adoption. Majority of the respondents adopted recommended practices and this may be probably because the respondents might be convinced about the benefits of the technology on sweet corn cultivation as well as farmers are getting very good price of sweet corn in local and peri-urban markets.

Table 1: Overall adoption level of recommended practices of sweet corn cultivation $(n=120)$

\begin{tabular}{llll}
\hline Category & $\begin{array}{l}\text { Frequency } \\
\text { (f) }\end{array}$ & $\begin{array}{l}\text { Percentage } \\
\mathbf{( \% )}\end{array}$ & \\
\hline $\begin{array}{l}\text { Low (Mean - } \\
\text { SD) }\end{array}$ & 20 & 16.7 & \\
$\begin{array}{l}\text { Medium (Mean } \\
\pm \text { SD) }\end{array}$ & 64 & 53.3 & Mean - 9.821 \\
$\begin{array}{l}\text { High (Mean }+ \\
\text { SD) }\end{array}$ & 36 & 30.0 & SD -2.304 \\
\hline
\end{tabular}

\section{Package of Practice wise adoption}

A total thirteen recommended practices were taken for the present study and adoption level was measured for each specific practice (Table 2). It was revealed that majority of the respondents $(75 \%)$ were adopting suitable sweet corn varietes like Sugar -75 and Madhuri because of good yield and the quality of grain and size of the cobs are fitting to the consumers demand. A medium level of adoption was seen in use of optimum seed rate $(70.8 \%)$, seed treatment $(51.7 \%)$, maintaining optimum plant population in field (55.0\%) followed by judicious use of fertilizer applications (48.3\%). The adoption level was very low in practices like

Table 2: Recommended package and practice wise adoption of production technology of sweet corn ( $\mathrm{n}=120)$

\begin{tabular}{|c|c|c|c|c|c|c|c|}
\hline \multirow{2}{*}{ S1. No. } & \multirow{2}{*}{ Cultivation Practices } & \multicolumn{2}{|c|}{ Full adoption } & \multicolumn{2}{|c|}{ Partial adoption } & \multicolumn{2}{|c|}{ Non adoption } \\
\hline & & $f$ & $\%$ & $\mathbf{f}$ & $\%$ & $\mathbf{f}$ & $\%$ \\
\hline 1 & Suitable Variety & 90 & 75.0 & 22 & 18.3 & 8 & 6.7 \\
\hline 2 & Seed rate & 20 & 16.7 & 85 & 70.8 & 15 & 12.5 \\
\hline 3 & Seed treatment & 28 & 23.3 & 62 & 51.7 & 30 & 25.0 \\
\hline 4 & Time of sowing & 78 & 65.0 & 20 & 16.7 & 22 & 18.3 \\
\hline 5 & Land preparation & 85 & 70.8 & 25 & 20.8 & 10 & 8.3 \\
\hline 6 & Method of sowing and spacing & 45 & 37.5 & 55 & 45.8 & 20 & 16.7 \\
\hline 7 & Optimum plant population & 24 & 20.0 & 66 & 55.0 & 30 & 25.0 \\
\hline 8 & Fertilizer application & 40 & 33.3 & 58 & 48.3 & 22 & 18.3 \\
\hline 9 & Irrigation management & 22 & 18.3 & 70 & 58.3 & 28 & 23.3 \\
\hline 10 & Intercultural operation & 40 & 33.3 & 56 & 46.7 & 24 & 20.0 \\
\hline 11 & Plant protection measure & 14 & 11.7 & 56 & 46.7 & 50 & 41.7 \\
\hline 12 & Weed Management & 30 & 25.0 & 45 & 37.5 & 45 & 37.5 \\
\hline 13 & Time of harvesting and Post harvest management & 35 & 29.2 & 75 & 62.5 & 10 & 8.3 \\
\hline
\end{tabular}

$f=$ Frequency. 
plant protection measures and weed Management (Table 2). Majority of the respondents were adopting optimum seed rate and maintaining optimum plant population as optimum plant population is the key attributing factor related to cob yield in sweet corn. Time of harvesting of green cob is the major factor for fetching good market price and it was found that more than half $(62.5 \%)$ of the respondents had shown medium level of adoption of optimum time of plucking the cobs with post harvest management followed by full adoption (29.2\%). The major differences were observed between recommended package of practices and farmer's practices are regarding plant protection measures and weed management, irrigation management practices followed by fertilizer application. The result is in conformity with the findings of Chaudhary et al. (2018) and Tiwari et al. (2003). It was also observed that farmers were unaware about plant protection measure $(41.7 \%)$, weed management $(37.5 \%)$, irrigation management $(23.3 \%)$ and maintaining optimum plant population $(25.0 \%)$. The findings are in corroborated with the findings of Singh and Chaudhury (1995) and Katare et al. (2011). By conducting front line demonstration of intervention practices of proven technologies in farmer's field, yield potential of sweet corn has enhanced to a great extent which increased in the income level of farmers and improved livelihood of farming community.

\section{Relationship between selected dependent and independent variables of the sweet corn growers}

Some of the selected socio-economic variables covered under study had significantly and positively influenced the knowledge and adoption level of the respondents (Table 3). The correlation coefficient, " $r$ " value indicated that education, social participation, cosmopoliteness, extension contact, communication materials used, holding size and annual income of the respondents were the important variables accelerating the knowledge and adoption level of the respondents toward adopting the recommended package and practices of sweet corn cultivation. Education, land holding, extension contact and communication material use were found to have positive and significant correlation at $5 \%$ level of significance. The socio- economic variables like education, extension contact, communication material used and holding size were the pertinent variables exhibiting influence towards adoption behaviour of the respondents.

Table 3: Influence of socio-economic variables on adoption level $(\mathrm{n}=120)$

\begin{tabular}{ll}
\hline Variables & $\begin{array}{l}\text { Correlation } \\
\text { Coefficient (r) }\end{array}$ \\
\hline Age & 0.172 \\
Education & $0.471^{* *}$ \\
Family type & -0.059 \\
Family size & 0.117 \\
Social participation & $0.257^{*}$ \\
Cosmopoliteness & $0.475^{*}$ \\
Extension contact & $0.681^{* *}$ \\
Communication material use & $0.515^{* *}$ \\
Type of house & 0.248 \\
Land holding & $0.521^{* *}$ \\
Occupation & 0.195 \\
Annual Income & $0.310^{*}$ \\
\hline
\end{tabular}

*Significant at 0.05 level, **Significant at 0.01 level.

\section{CONCLUSION}

From the findings it was concluded that majority of the respondents $(83.3 \%)$ were found to possess medium to high level of adoption behavior regarding different recommended package and practices about sweet corn cultivation. It means that the respondents were more energetic, progressive and adopting the sweet corn as cash crop keeping the market demand in mind and practicing the technologies for better production and higher net return. The socio economic variables like education, land holding, extension contact and communication material used were found to be positive and significantly correlated with adoption of recommended technologies of sweet corn cultivation. This means that big farmers having more land holdings and educated farmers with high extension contact had grater adoption level of sweet corn cultivation as they had access to market and possessed more risk bearing ability. Use of scientific methods and technological practices of sweet corn cultivation can reduce the technological gap to a considerable extent thus leading to higher productivity of sweet corn in the district. FLD programme was a successful tool for enhancing the production and productivity of sweet corn in this 
district and efforts are being made at different levels to maximize the area, production and productivity of sweet corn in this region. Moreover, extension agencies like KVK, ATMA, NGO's of the district need to provide more technical support to the farmers through demonstration, capacity building programme, exposure visit to other fields and field days which can increase the horizontal spread of the technology to more number of farmers in the district.

\section{REFERENCES}

Adinurani, P.G., Rahayu, S., Budi, L.S., Pambudi, S. and Soni, P. 2019. Production potensial of sweet corn (Zea mays Linn. var. Saccharata Sturt ) 'Bonanza' to different planting pattern and phosphorus sources. The $2^{\text {nd }}$ International Conference on Natural Resources and Life Sciences (NRLS) IOP Conf. Ser.: Earth and Environmental Science, pp. 1-7.

Bello, O.B., Abdulmaliq, S.Y., Afolabi, M.S. and Lge, S.A. 2010. Correlation and path coefficient analysis of yield and agronomic characters among open pollinated maize varieties and their F1 hybrids in a diallel cross. African Journal of Biotechnology, 9(18): 2633-2639.

Bhatt, P.S. 2012. Response of sweet corn hybrid to varying plant densities and nitrogen levels. African Journal of Agricultural Research, 7(46): 6158-6166.

Chaudhary, R.P., Choudhary, G.K., Prasad, R., Singh, R. and Chaturvedi, A.K. 2018. Impact Assessment of Front Line Demonstration on Mustard Crop. International Journal of Current Microbiology and Applied Sciences, 7: 4737-4742.
Katare, S., Pandey, S.K. and Mustafa, M. 2011. Yield gap analysis of Rapeseed-mustard through front line demonstration. Agriculture update, 6(2): 5-7.

Najeeb, S. 2011. Popularization of sweet corn (Zea mays L. saccharata) under temperate conditions to boost the socioeconomic conditions. Maize Genetics Cooperation Newsletter, 85: 54-59.

Priyambada, S. 2017. District Level Poverty in Odisha: Depth \& Severity of Poverty: Planning Convergence Department, Govt. of Odisha.

Randjelovic, V., Prodanovic, S., Tomic, Z. and Simic, A. 2011. Genotype $x$ year effect on grain yield and nutritive values of maize (Zea mays L.). Journal of Animal and Veterinary Advances, 10(7): 835-840.

Singh, A.L. and Chaudhari, V. 1995. Source and mode of sulphur application on groundnut productivity. Journal of Plant Nutrition, 18(12): 2739-2759.

Tiwari, R.B., Singh, V. and Parihar, P. 2003. Role of frontline demonstrations in transfer of gram production technology. Maharashtra Journal of Extension Education, 22(1): 19.

Venkatasubramanian, V., Sajeev, M.V. and Singha, A.K. 2010. Concept, Approaches and Mythologies for Technology Application and Transfer, ICT led Knowledge management in KVKs, The Zonal Project Directorate Zone -III, ICAR, Umiam, Meghalaya Chapter -IX, pp. 85-86.

Walker, S. 2018. Home and market garden sweet corn production (Original author: George WD). Cooperative Extension Service, College of Agricultural, Consumer and Environmental Sciences, New Mexico State University. https://aces.nmsu.edu/pubs/_h/H223.pdf, pp. 4. 
